Bull. Chem. Soc. Ethiop. 2019, 33(2), 255-268.

ISSN 1011-3924

(c) 2019 Chemical Society of Ethiopia and The Authors

Printed in Ethiopia

DOI: https://dx.doi.org/10.4314/bcse.v33i2.6

\title{
SYNTHESIS, CHARACTERIZATION AND ANTIMICROBIAL ACTIVITIES OF SOME 5-BROMOURACIL-METAL ION COMPLEXES
}

\author{
Said M. Teleb ${ }^{1}$, Muhammad E. Askar ${ }^{1}$, Samar A. El-Kalyoubi ${ }^{2}$ and Akmal S. Gaballa ${ }^{3 *}$ \\ ${ }^{1}$ Chemistry Department, Faculty of Science, Zagazig University, Zagazig, Egypt \\ ${ }^{2}$ Faculty of Pharmacy (Girls), Al-Azhar University, Cairo, Egypt \\ ${ }^{3}$ Faculty of Specific Education, Zagazig University, Zagazig, Egypt
}

(Received September 14, 2018; Revised February 27, 2019; Accepted April 1, 2019)

\begin{abstract}
Six new complexes, $\left[\mathrm{Mn}(\mathrm{Br}-\mathrm{U})_{2}\left(\mathrm{H}_{2} \mathrm{O}\right)_{2}\right] \cdot 4 \mathrm{H}_{2} \mathrm{O} \quad(\mathbf{1}), \quad\left[\mathrm{Cd}(\mathrm{Br}-\mathrm{U})_{2}\right] \cdot 2 \mathrm{H}_{2} \mathrm{O} \quad$ (2), $\left[\mathrm{Cu}(\mathrm{Br}-\mathrm{U})_{2}\left(\mathrm{H}_{2} \mathrm{O}\right)_{2}\right] \cdot 2 \mathrm{H}_{2} \mathrm{O} \quad(\mathbf{3}), \quad\left[\mathrm{Co}(\mathrm{Br}-\mathrm{U})_{2}\left(\mathrm{H}_{2} \mathrm{O}\right)_{2}\right] \cdot 4 \mathrm{H}_{2} \mathrm{O} \quad$ (4), $\quad\left[\mathrm{Ni}(\mathrm{Br}-\mathrm{U})_{2}\left(\mathrm{H}_{2} \mathrm{O}\right)_{2}\right] \cdot 4 \mathrm{H}_{2} \mathrm{O} \quad$ (5) and $[\mathrm{Ag}(\mathrm{Br}-\mathrm{U})(\mathrm{Br}-\mathrm{U}-\mathrm{H})] \cdot 2\left(\mathrm{H}_{2} \mathrm{O}\right)$ (6) were prepared by the reaction of 5 -bromoouracil with $\mathrm{MnCl}_{2} \cdot 4 \mathrm{H}_{2} \mathrm{O}$, $\mathrm{CdCl}_{2} \cdot 2.5 \mathrm{H}_{2} \mathrm{O}, \quad \mathrm{CuSO}_{4} \cdot 5 \mathrm{H}_{2} \mathrm{O},\left(\mathrm{CH}_{3} \mathrm{COO}\right)_{2} \mathrm{Co} \cdot 4 \mathrm{H}_{2} \mathrm{O}, \quad\left(\mathrm{CH}_{3} \mathrm{COO}\right)_{2} \mathrm{Ni}^{2} \cdot 4 \mathrm{H}_{2} \mathrm{O}$ and $\mathrm{AgNO}_{3}$ respectively. The complexes were characterized by melting point, elemental microanalyses, IR and ${ }^{1} \mathrm{H}$ NMR spectroscopy. The obtained data indicated that the ligand interacted with the metal ions in its mononegatively charged enol form in a bidentate fashion. Thermogravimetric analyses (TGA and DTG) were also carried out. The data obtained agreed well the proposed structures and showed that the complexes were finally decomposed to the corresponding metal or metal oxide. The ligand and its metal-ion complexes were tested for their antimicrobial activities against four bacterial strains (B. subtillis, S. aureus, E. coli and P. aeruginosa) by the agar-well diffusion technique using DMSO as a solvent. The obtained data showed that the complexes were more potent antimicrobial agents than the parent ligand.
\end{abstract}

KEY WORDS: 5-Bromoouracil- $\mathrm{M}^{2+}$ complexes, IR, Thermal analyses, ${ }^{1} \mathrm{H}$ NMR, Antimicrobial activity

\section{INTRODUCTION}

Uracil is a naturally occurring nucleic acid [1] and is the most important pyrimidine base that represents remarkable roles in the structures and functions of enzymes and drugs [2]. In recent years, uracil and its derivatives and complexes have been used in the synthesis of antibacterial, antiviral and anti-tumour agents [3-5]. Intensive investigations have shed light on the natures of the interactions between metal ions and nucleic acid bases, including their abilities to form complexes [2] which have wide-ranging biological activities, such as antimalarial, antitumoural, antibacterial, and antiviral activities $[6,7]$.

5-Bromouracil (Br-U-H), (5-bromopyrimidine-2,4(1H,3H)-dione) (Scheme 1), is a halogenated derivative of uracil which has the ability to terminate DNA replication in viruses and other cell culture systems [8-11]. This termination of DNA replication occurs via the replacement of a thymine base in the genetic code with 5-bromouracil, resulting in an unusual code that stops the replication process $[12,13]$. On the other hand, the thymine replacement by 5-bromouracil in the DNA genetic sequence has a significant influence on cancer therapy, leading to higher sensitivity to ionizing radiation $[14,15]$ without influencing the un-irradiated cells. Moreover, 5-bromouracil has a great influence on the growth of viruses, bacteria and other microorganisms [8-11]. Heterocyclic molecules have tautomeric forms at equilibrium in solutions, where hydrogen atoms can move to various locations within the molecules. In this respect, 5-bromouracil isomers exist in enol and keto tautomeric forms [13], Scheme 2.

*Corresponding author. E-mail: akmalsg@yahoo.com

This work is licensed under the Creative Commons Attribution 4.0 International License 
<smiles>[X]c1c[nH]c(=O)[nH]c1=O</smiles>

$$
\text { where } \mathrm{X}=\mathrm{H} \text { (uracil) } \quad \mathrm{X}=\mathrm{Br} \text { (5-bromouracil) }
$$

Scheme 1. Molecular structure of uracil and 5-bromouracil.<smiles>C=CC=C</smiles>

Keto form<smiles>O=c1nc(O)c(Br)c[nH]1</smiles>

Enol form

Scheme 2. Tautomeric forms of bromouracil.

At alkaline $\mathrm{pH}$ values, the hydrogen atom bonded to the $\mathrm{N}(3)$ atom in the keto form of 5 bromouracil is removed, indicating that the $\mathrm{N}(3)$ hydrogen atom is acidic $\left(\mathrm{pK}_{\mathrm{a}}=8\right)$; however, the $\mathrm{N}(1)$ atom is basic $[13,16]$. 5-Bromouracil is a nucleotide base that can bind to metals or bind to tissues via metals [17-19]. Additionally, its complexes or compounds have been identified as biologically active materials acting as antibacterial and anti-tumour agents [18, 20].

In this article, the preparation, characterization and biological activities of $\mathrm{Mn}(\mathrm{II}), \mathrm{Cd}(\mathrm{II})$, $\mathrm{Co}(\mathrm{II}), \mathrm{Ni}(\mathrm{II}), \mathrm{Cu}(\mathrm{II})$ and $\mathrm{Ag}(\mathrm{I})$ complexes with 5-bromouracil has been described. The determination of the binding sites of 5-bromouracil with these metal ions can give additional value by correlating the coordination modes of 5-bromouracil with its biological activity. The obtained complexes were characterized by elemental analysis, infrared (IR) spectroscopy, ${ }^{1} \mathrm{H}$ nuclear magnetic resonance (NMR) spectroscopy, melting point, conductivity measurements as well as thermal analysis (thermogravimetric analysis, TGA, and differential thermogravimetric analysis, DTG).

\section{EXPERIMENTAL}

Materials and spectral measurements

Reagents

5-Bromouracil, $\mathrm{KOH}$ and metal salts, i.e. $\mathrm{MnCl}_{2} \cdot 4 \mathrm{H}_{2} \mathrm{O}, \mathrm{CdCl}_{2} \cdot 2.5 \mathrm{H}_{2} \mathrm{O}, \mathrm{CuSO}_{4} \cdot 5 \mathrm{H}_{2} \mathrm{O}$, $\mathrm{Co}\left(\mathrm{CH}_{3} \mathrm{COO}\right)_{2} \cdot 4 \mathrm{H}_{2} \mathrm{O}, \mathrm{Ni}\left(\mathrm{CH}_{3} \mathrm{COO}\right)_{2} \cdot 4 \mathrm{H}_{2} \mathrm{O}$ and $\mathrm{AgNO}_{3}$, used in this study were purchased in analytical grade and used without further purification.

Instruments

Elemental analysis for $\mathrm{C}, \mathrm{H}$ and $\mathrm{N}$ was carried out in the Microanalysis Department of Cairo University, Egypt, using a VARIO EL III elemental analyzer. Infrared measurements (KBrpellets) were carried out on a Unicam SP 1000 IR spectrophotometer (Pharmaceutical 
Analytical Department, Al-Azhar University, Cairo, Egypt). ${ }^{1} \mathrm{H}$ NMR measurements were performed using DMSO as a solvent on a Bruker spectrometer (Zagazig University, NMR Department, Zagazig, Egypt). TGA was carried out at a heating rate of $10{ }^{\circ} \mathrm{C}$ using a Universal TGA Q500 instrument (Science \& Technology Center of Excellence, Cairo, Egypt). Molar conductivities of the complex solutions $\left(1 \times 10^{-3} \mathrm{M}\right)$ in dimethylformamide (DMF) were measured at room temperature using a Jenway 4510 conductivity meter. The heavy metals which include manganese $(\mathrm{Mn})$, cadmium $(\mathrm{Cd})$, copper $(\mathrm{Cu})$, cobalt $(\mathrm{Co})$, nickel $(\mathrm{Ni})$, and silver (Ag) are detected by ICP Spectrophotometer Thermo Jarrel Ash model POEMS 3, using 1000 $\mathrm{mg} / \mathrm{L}$ (Merck) stock solution for standard preparations.

\section{Preparation of the ligand solution}

5-Bromouracil (764.0 mg, $4.0 \mathrm{mmol})$ was suspended in $30.0 \mathrm{~mL}$ of distilled $\mathrm{H}_{2} \mathrm{O},(\mathrm{pH}=4.2)$, and a $\mathrm{KOH}$ solution $(1.0 \mathrm{M})$ was added dropwise until reaching $\mathrm{pH}$ to 10 or and complete dissolution of the ligand.

\section{Syntheses of the metal complexes}

To the prepared ligand solution, $50.0 \mathrm{~mL}$ of an aqueous solution $(2.0 \mathrm{mmol})$ of the corresponding metal salt, i.e. $\mathrm{MnCl}_{2} \cdot 4 \mathrm{H}_{2} \mathrm{O}(395.0 \mathrm{mg}), \mathrm{CdCl}_{2} \cdot 2.5 \mathrm{H}_{2} \mathrm{O}(456.0 \mathrm{mg}), \mathrm{CuSO}_{4} \cdot 5 \mathrm{H}_{2} \mathrm{O}$ $(499.0 \mathrm{mg}), \mathrm{Co}\left(\mathrm{CH}_{3} \mathrm{COO}\right)_{2} \cdot 4 \mathrm{H}_{2} \mathrm{O}(498.0 \mathrm{mg}), \mathrm{Ni}\left(\mathrm{CH}_{3} \mathrm{COO}\right)_{2} \cdot 4 \mathrm{H}_{2} \mathrm{O}(497.0 \mathrm{mg})$ or $\mathrm{AgNO}_{3}$ $\left(393.7 \mathrm{mg}\right.$ ), was added. The reaction mixture was stirred for around $5 \mathrm{~h}$ at $65{ }^{\circ} \mathrm{C}$. The obtained precipitate was filtered, washed several times with a few drops of distilled water, and then dried in an oven $\left(50^{\circ} \mathrm{C}\right)$ for $2 \mathrm{~h}$ and then in a silica gel desiccator.

[Mn $\left(\mathrm{Br}-\mathrm{U}_{2}\left(\mathrm{H}_{2} \mathrm{O}\right)_{2}\right] \cdot 4 \mathrm{H}_{2} \mathrm{O}$ (1). Yield: $(50.10 \%)$. M.P.: $340{ }^{\circ} \mathrm{C}$. Colour: yellowish brown. Analysis found\% (calculated \% for $\mathrm{C}_{8} \mathrm{H}_{16} \mathrm{Br}_{2} \mathrm{MnN}_{4} \mathrm{O}_{10}, 542.98$ ): C, 18.05 (17.70); H, 2.96 (2.97); Mn 10.19 (10.12); N, 10.74 (10.32).

$\left[\mathrm{Cd}(\mathrm{Br}-\mathrm{U})_{2}\right] \cdot 2 \mathrm{H}_{2} \mathrm{O}$ (2). Yield: (39.60\%). M.P.: $>350{ }^{\circ} \mathrm{C}$. Colour: white. Analysis found\% (calculated \% for $\mathrm{C}_{8} \mathrm{H}_{8} \mathrm{Br}_{2} \mathrm{CdN}_{4} \mathrm{O}_{6}, 528.39$ ): C, 18.24 (18.18); H, 1.99 (1.53); Cd, 21.50 (21.27), N, 10.34 (10.60).

$\left[\mathrm{Cu}(\mathrm{Br}-\mathrm{U})_{2}\left(\mathrm{H}_{2} \mathrm{O}\right)_{2}\right] \cdot 2 \mathrm{H}_{2} \mathrm{O}$ (3). Yield: (65.80\%). M.P.: $295^{\circ} \mathrm{C}$. Colour: green. Analysis found\% (calculated \% for $\mathrm{C}_{8} \mathrm{H}_{12} \mathrm{Br}_{2} \mathrm{CuN}_{4} \mathrm{O}_{8}, 515.56$ ): C, 18.23 (18.64); $\mathrm{H}, 2.52$ (2.35); $\mathrm{Cu}, 12.48$ (12.33); N, 10.54 (10.87).

[Co $\left.(\mathrm{Br}-\mathrm{U})_{2}\left(\mathrm{H}_{2} \mathrm{O}\right)_{2}\right] \cdot 4 \mathrm{H}_{2} \mathrm{O}$ (4). Yield: $(66.90 \%)$. M.P: $315{ }^{\circ} \mathrm{C}$. Colour: red. Analysis found $\%$ (Calculated\% for $\left.\mathrm{C}_{8} \mathrm{H}_{16} \mathrm{Br}_{2} \mathrm{CoN}_{4} \mathrm{O}_{10}, 546.97\right)$ : C, 17.50 (17.57); H, 3.33 (2.95); Co, 10.89 (10.77); N 10.43 (10.24).

[Ni(Br-U $\left.)_{2}\left(\mathrm{H}_{2} \mathrm{O}\right)_{2}\right] \cdot 4 \mathrm{H}_{2} \mathrm{O}$ (5). Yield: $(85.90 \%)$. M.P.: $318{ }^{\circ} \mathrm{C}$. Colour: faint green. Analysis found $\%$ (calculated $\%$ for $\mathrm{C}_{8} \mathrm{H}_{16} \mathrm{Br}_{2} \mathrm{~N}_{4} \mathrm{NiO}_{10}, 546.73$ ): $\mathrm{C}, 17.60$ (17.57); $\mathrm{H}, 3.03$ (2.95); Ni, 10.81 (10.74); N, 10.34 (10.25).

$[\mathrm{Ag}(\mathrm{Br}-\mathrm{U})(\mathrm{Br}-\mathrm{U}-\mathrm{H})] \cdot 2 \mathrm{H}_{2} \mathrm{O}$ (6). Yield: (88.40\%). M.P.: $278{ }^{\circ} \mathrm{C}$. Colour: white silvery. Analysis found\% (calculated \% for $\mathrm{C}_{8} \mathrm{H}_{9} \mathrm{AgBr}_{2} \mathrm{~N}_{4} \mathrm{O}_{6}, 524.86$ ): C, 17.98 (18.31); H, 1.79 (1.73); Ag, 21.05 (20.55); N, 10.36 (10.67). 
Antimicrobial activity

The in vitro antibacterial effects of the compounds were tested against four bacterial strains, i.e. $E$. coli and $P$. aeruginosa (Gram-negative bacteria) and B. subtillis and S. aureus (Grampositive bacteria), by an agar well diffusion method using nutrient agar medium [21-23]. All bacteria were inoculated into nutrient broth and incubated for $24 \mathrm{~h}(1.0 \mathrm{~mL}$ of inoculant was added to $50 \mathrm{~mL}$ of agar media $\left(50^{\circ} \mathrm{C}\right)$ and mixed). The agar was poured into $120 \mathrm{~mm}$ petri dishes and allowed to cool to room temperature. In the agar well diffusion method, the dilution plate method was used to enumerate microorganisms for $24 \mathrm{~h}[24,25]$. Using a sterilized cork borer ( $7 \mathrm{~mm}$ diameter), wells were dug into the culture plates. The compounds dissolved in DMSO $(0.1 \mathrm{~mL}, 250 \mu \mathrm{mol} / \mathrm{mL})$ were added to these wells. The petri dishes were left at $5{ }^{\circ} \mathrm{C}$ for $2 \mathrm{~h}$, and then, the plates were incubated at $35^{\circ} \mathrm{C}$ for bacterial growth $(24 \mathrm{~h})$. At the end of the period, the inhibition zones formed on the medium were evaluated in millimetres ( $\mathrm{mm}$ ). DMSO $(0.1 \mathrm{~mL})$ was used as a control under similar conditions. The inhibition zones based on the zone size around the discs were measured and calculated as means of triplicates and are reported as average values of three experiments.

\section{RESULTS AND DISCUSSION}

\section{Free ligand and complexes}

All the prepared complexes are insoluble in many organic solvents (methanol, ethanol, acetonitrile, chloroform, carbon tetrachloride) and water. Complexes 1, 4 and 6 are soluble in DMF, while the other complexes $\mathbf{2 , 3}$ and $\mathbf{5}$ are slightly or sparingly soluble in DMF. These complexes were characterized by IR, ${ }^{1} \mathrm{H}$ NMR spectroscopy, melting point measurements, elemental analyses and TGA. The complexes have a 1:2 metal-to-ligand stoichiometry.

\section{Conductance}

The conductivity values measured at $25{ }^{\circ} \mathrm{C}$ in DMF for $10^{-3} \mathrm{M}$ solutions of the free ligand and its complexes are very small, and their values lie in the range of $3.17-8.2 \mu \mathrm{s}^{\cdot} \mathrm{cm}^{-1}$, indicating the non-electrolytic nature of the complexes [26].

\section{IR spectra}

The infrared spectrum of the free ligand (Table 1) shows a strong broad band at $1677 \mathrm{~cm}^{-1}$ characteristic of $(\mathrm{C}(4)=\mathrm{O})$ and a shoulder at $1617 \mathrm{~cm}^{-1}$ corresponding to $(\mathrm{C}(2)=\mathrm{O})$, which are practically overlapped. Two weak/medium bands are observed at 3360 and $3168 \mathrm{~cm}^{-1}$, which may be assigned to $(\mathrm{N}(3)-\mathrm{H})$ and $(\mathrm{N}(1)-\mathrm{H})$ stretching vibrations, respectively.

The assignments of the well-defined bands in the infrared spectra of the complexes are summarized in Table 1 . The $v(C=O)$ of the free ligand is observed at $1677 \mathrm{~cm}^{-1}$, while the corresponding vibrations in the metal complexes are observed in the range of $1611-1640 \mathrm{~cm}^{-1}$. A shift of $30-50 \mathrm{~cm}^{-1}$ to lower frequencies is observed for the carbonyl band after coordination with the metal ions, clearly indicating the coordination of the carbonyl group to the metal ions. The disappearance of the absorption band at $3360 \mathrm{~cm}^{-1}(\mathrm{~N}(3)-\mathrm{H}$ in the free ligand spectrum) in the complex spectra indicates that the $\mathrm{N}(3)$ atom is bound to the metal ions. The complex spectra show an absorption band in the range of $1590-1525 \mathrm{~cm}^{-1}$. This band is not observed in the spectrum of the free ligand and may be attributed to the stretching motion associated with the $\mathrm{C}=\mathrm{N}$ bond resulting from the transformation of the ligand from the keto form to the enol form upon complexation. The observation of such a band in the complex spectra support the assumption that 5-bromouracil is coordinated with the metal ions as a mononegative bidentate 
ligand through one oxygen atom of the carbonyl group and the N(3) atom. This coordination mode is also supported by the observation of two weak bands in the ranges of 609-563 and $550-510 \mathrm{~cm}^{-1}$, which are attributed to $\mathrm{M}-\mathrm{N}$ and $\mathrm{M}-\mathrm{O}$ stretching modes, respectively. These two bands are not observed in the spectrum of the free ligand [27-31].

According to the forgoing discussion and based on the proposed molecular formulas, the probable structures of the $\mathrm{Mn}(\mathrm{II}), \mathrm{Co}(\mathrm{II}), \mathrm{Ni}(\mathrm{II})$, and $\mathrm{Co}(\mathrm{II})$ complexes are in octahedral geometries. On other hand, the structures for the $\mathrm{Cd}(\mathrm{II})$ and $\mathrm{Ag}(\mathrm{I})$ complexes are more likely in tetrahedral geometries, as shown in Scheme 3 [32-36].

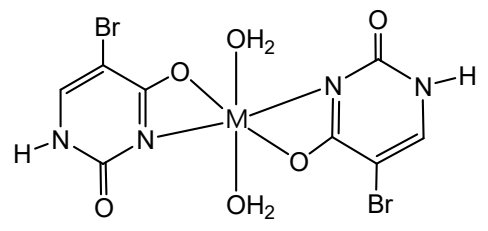

where $\mathrm{M}=\mathrm{Mn}(\mathrm{II}), \mathrm{Co}(\mathrm{II}), \mathrm{Ni}(\mathrm{II})$ or $\mathrm{Cu}(\mathrm{II})$<smiles>O=c1nc2c(Br)c(n1COc1ncc(Br)c(Cl)n1)O2</smiles><smiles></smiles>

Scheme 3. Suggested structures for the 5-bromouracil-metal ion complexes.

Table 1. Selected IR frequencies $\left(\mathrm{cm}^{-1}\right)$ and tentative assignments for 5-bromouracil (as a free ligand) and its metal complexes (1-6).

\begin{tabular}{|l|l|l|l|l|l|l|l|}
\hline$(\mathrm{Br}-\mathrm{U}-\mathrm{H})$ & $\mathbf{1}$ & $\mathbf{2}$ & $\mathbf{3}$ & $\mathbf{4}$ & $\mathbf{5}$ & $\mathbf{6}$ & Assignments \\
\hline $3467 \mathrm{w}, \mathrm{br}$ & $3448 \mathrm{vs}$ & $3415 \mathrm{~s}, \mathrm{br}$ & $3409 \mathrm{vs}, \mathrm{br}$ & $3433 \mathrm{vs}, \mathrm{br}$ & $3440.3 \mathrm{vs}, \mathrm{br}$ & $3419 \mathrm{w}, \mathrm{br}$ & $\mathrm{v}(\mathrm{O}-\mathrm{H}), \mathrm{H}{ }_{2} \mathrm{O}$ \\
\hline $3360 \mathrm{sh}$ & ------ & ----- & ------ & ------ & ----- & ----- & $v(\mathrm{~N} 3-\mathrm{H})$ \\
\hline $3168 \mathrm{~m}$ & $3187 \mathrm{~m}$ & $3137 \mathrm{w}, \mathrm{br}$ & $3202 \mathrm{w}$ & $3118 \mathrm{~m}$ & $3117 \mathrm{~s}$ & $3150 \mathrm{w}$ & $\mathrm{v}(\mathrm{N} 1-\mathrm{H})$ \\
\hline $3060 \mathrm{~m}$ & $3125 \mathrm{~m}$ & $3020 \mathrm{w}, \mathrm{br}$ & $3077 \mathrm{vw}$ & $3029 \mathrm{vw}$ & $3029 \mathrm{vw}$ & $3048 \mathrm{vw}$ & $\mathrm{v}(\mathrm{C}-\mathrm{H})$, aromatic \\
\hline $1677 \mathrm{vs}$ & $1612 \mathrm{vs}$ & $1641 \mathrm{~s}$ & $1643 \mathrm{vs}$ & $1611 \mathrm{~s}$ & $1618 \mathrm{vs}$ & $1640 \mathrm{vs}$ & $\mathrm{v}(\mathrm{C}=\mathrm{O})$ \\
\hline----- & $1590 \mathrm{sh}$ & $1572 \mathrm{w}$ & $1578 \mathrm{sh}$ & $1576 \mathrm{~s}$ & $1573 \mathrm{vs}$ & $1525 \mathrm{vs}$ & $\mathrm{v}(\mathrm{C}=\mathrm{N})$ \\
\hline $1427 \mathrm{~s}$ & $1392 \mathrm{~s}$ & $1454 \mathrm{~s}$ & $1470 \mathrm{~m}$ & $1389 \mathrm{vs}$ & $1394 \mathrm{vs}$ & $1404 \mathrm{~m}$ & $\mathrm{v}(\mathrm{C}-\mathrm{C}) ; \delta(\mathrm{N} 1-\mathrm{H})$ \\
\hline $1224 \mathrm{~m}$ & $1271 \mathrm{~m}$ & $1274 \mathrm{~m}$ & $1281 \mathrm{~m}$ & $1272 \mathrm{vs}$ & $1278 \mathrm{~m}$ & $1273 \mathrm{~m}$ & $v(\mathrm{C}-\mathrm{N}) ; \mathrm{v}(\mathrm{C}-\mathrm{O})$ \\
\hline $1054 \mathrm{w}$ & $1010 \mathrm{~m}$ & $1026 \mathrm{~s}$ & $1063 \mathrm{~m}$ & $1080 \mathrm{~m}$ & $1082 \mathrm{w}$ & $1068 \mathrm{w}$ & $\mathrm{v}(\mathrm{C}-\mathrm{Br})$ \\
\hline------ & $583 \mathrm{w}$ & $562 \mathrm{sh}$ & $609 \mathrm{sh}$ & $586 \mathrm{~m}$ & $592 \mathrm{w}$ & $576 \mathrm{~m}$ & $\mathrm{v}(\mathrm{M}-\mathrm{N})$ \\
\hline------ & $550 \mathrm{sh}$ & $509 \mathrm{sh}$ & $536 \mathrm{w}$ & $520 \mathrm{w}$ & $517 \mathrm{vw}$ & $477 \mathrm{w}$ & $v(\mathrm{M}-\mathrm{O})$ \\
\hline
\end{tabular}

Where, $\mathrm{sh}=$ shoulder, $\mathrm{s}=$ strong, $\mathrm{m}=$ medium, $\mathrm{w}=$ weak, $\mathrm{br}=$ broad, $\mathrm{v}=$ very. 
${ }^{1} H$ NMR spectra

The ${ }^{1} \mathrm{H}$ NMR spectral data of free 5-bromouracil and its $\mathrm{Cd}(\mathrm{II})$ and $\mathrm{Ag}(\mathrm{I})$ complexes in DMSO are summarized in Table 2. The spectra reveal a characteristic signal for the aromatic proton in its expected region of $7.00-8.00 \mathrm{ppm}$. The $\mathrm{N}(1)-H$ signal is located at $11.13 \mathrm{ppm}$ in the spectrum of the free ligand, while the corresponding signals in the spectra of the $\mathrm{Cd}(\mathrm{II})$ and $\mathrm{Ag}(\mathrm{I})$ complexes are observed at 10.90 and $10.85 \mathrm{ppm}$, respectively. The $\mathrm{N}(3)-H$ signal in the free ligand spectrum $(11.51 \mathrm{ppm})$ is absent in the spectra of the complexes, which is consistent with the forgoing suggestion that 5-bromouracil reacted with the metal ions through its enol form. The $\operatorname{Ag}(\mathrm{I})$ complex exhibits a signal at $10.51 \mathrm{ppm}$, and such a signal is neither present in the spectrum of the free ligand nor in the spectra of the other complexes. This signal may be attributed to the $(\mathrm{O}-H)$ proton associated with one of the two ligands coordinated with the $\mathrm{Ag}(\mathrm{I})$ ion. Accordingly, one of the two ligands bonded to the $\operatorname{Ag}(\mathrm{I})$ ion is a neutral molecule in the enol form, while the other is negatively charged, as shown in Scheme III. The ${ }^{1} \mathrm{H}$ NMR spectrum of the free ligand confirms the results obtained from the IR spectrum. The obtained data suggests that 5-bromouracil is in the keto form. Dissolving the base with additional $\mathrm{KOH}$ converts the keto form to the enol form, forming a soluble salt with the deprotonation of $\mathrm{N}(3)-H$ as the $\mathrm{pH}$ is raised to $10[37,38]$.

Table 2. ${ }^{1} \mathrm{H}$ NMR data in ppm and assignments for 5-bromouracil as a free ligand and its $\mathrm{Cd}(\mathrm{II})$ and $\mathrm{Ag}(\mathrm{I})$ complexes.

\begin{tabular}{|l|l|l|l|l|l|}
\hline Compound & $\mathrm{C}_{6}-H$ & $\mathrm{~N}_{1}-H$ & $\mathrm{~N}_{3}-H$ & $\mathrm{O}-H$ & $H_{2} \mathrm{O}$ \\
\hline Free ligand $(\mathrm{Br}-\mathrm{U}-\mathrm{H})$ & $7.88(1 \mathrm{H})$ & 11.13 & $11.51(1 \mathrm{H})$ & ----- & 3.35 \\
\hline$\left[\mathrm{Cd}(\mathrm{Br}-\mathrm{U})_{2}\right] \cdot 4 \mathrm{H}_{2} \mathrm{O}(2)$ & $7.85(1 \mathrm{H})$ & 10.90 & ---- & ---- & 3.34 \\
\hline$[\mathrm{Ag}(\mathrm{Br}-\mathrm{U})(\mathrm{Br}-\mathrm{U}-\mathrm{H})] \cdot 2 \mathrm{H}_{2} \mathrm{O}(\mathbf{6})$ & $7.80(1 \mathrm{H})$ & 10.85 & ---- & $10.51(1 \mathrm{H})$ & 3.32 \\
\hline
\end{tabular}

\section{Thermal analyses}

To confirm the proposed structures of the complexes, thermogravimetric analyses (TGA) were performed. The thermal data for all complexes are summarized in Table 3. The free ligand completely decomposes in one step at approximately $320^{\circ} \mathrm{C}$, as shown in Figure 1, indicating its pure organic structure.

The decomposition reactions of $\left[\mathrm{Mn}(\mathrm{Br}-\mathrm{U})_{2}\left(\mathrm{H}_{2} \mathrm{O}\right)_{2}\right] \cdot 4 \mathrm{H}_{2} \mathrm{O}, \quad\left[\mathrm{Cd}(\mathrm{Br}-\mathrm{U})_{2}\right] \cdot 2 \mathrm{H}_{2} \mathrm{O}$, $\left[\mathrm{Cu}(\mathrm{Br}-\mathrm{U})_{2}\left(\mathrm{H}_{2} \mathrm{O}\right)_{2}\right] \cdot 2 \mathrm{H}_{2} \mathrm{O}, \quad\left[\mathrm{Co}(\mathrm{Br}-\mathrm{U})_{2}\left(\mathrm{H}_{2} \mathrm{O}\right)_{2}\right] \cdot 4 \mathrm{H}_{2} \mathrm{O}, \quad\left[\mathrm{Ni}(\mathrm{Br}-\mathrm{U})_{2}\left(\mathrm{H}_{2} \mathrm{O}\right)_{2}\right] \cdot 4 \mathrm{H}_{2} \mathrm{O} \quad$ and [Ag(Br-U) $(\mathrm{Br}-\mathrm{U}-\mathrm{H})] \cdot 2 \mathrm{H}_{2} \mathrm{O}$ occur in four, five or six steps from $120^{\circ} \mathrm{C}$ to $1000{ }^{\circ} \mathrm{C}$, as shown in Figure 1. In these complexes, the first decomposition step proceeds at a temperature between $120{ }^{\circ} \mathrm{C}$ and $210{ }^{\circ} \mathrm{C}$ with a weight loss ranging from of $6.30-13.50 \%$, associated with the loss of the outer-sphere (uncoordinated) water content. The calculated ratio of the outer-sphere water content in the suggested forms is between $6.82 \%$ and $13.27 \%$, in good agreement with the observed values (Table 3 ).

The second thermal decomposition step for complexes $\mathbf{1 , 3}, \mathbf{4}$, and 5 displayed weight loss in the range of $6.71-7.50 \%$ at a temperature range of $240-275^{\circ} \mathrm{C}$, which may be attributed to the loss of coordinated water. This result agrees with the calculated coordinated water values of $6.59-6.99 \%$ in the suggested formulas of these complexes. The TGA thermograms of complexes $\mathbf{2}$ and $\mathbf{6}$ shows no weight loss in this temperature range, indicating the absence of any coordinated water, which is consistent with the suggested formulas of both complexes.

The loss of organic content associated with the ligands occurs in the next two to six decomposition steps at maximum temperatures between $283{ }^{\circ} \mathrm{C}$ and $925{ }^{\circ} \mathrm{C}$. The weight loss associated with these decomposition steps $(65.75-78.49 \%)$ is in agreement with the calculated values $(66.54-72.59 \%)$. The total weight loss throughout the decomposition process lies in the 
Table 3. The maximum temperature values for the decomposition along with the species lost in each step of the decomposition reactions of 5-bromouracil and its complexes.

\begin{tabular}{|c|c|c|c|c|c|}
\hline \multirow[b]{2}{*}{ Complex } & \multirow[b]{2}{*}{ Decomposition } & \multirow[b]{2}{*}{$\mathrm{T}_{\max }\left({ }^{\circ} \mathrm{C}\right)$} & \multirow[b]{2}{*}{ Lost species } & \multicolumn{2}{|c|}{$\%$ of weight loss } \\
\hline & & & & Found & Calcd \\
\hline Free ligand $(\mathrm{Br}-\mathrm{U}-\mathrm{H})$ & one step & 320 & $\mathrm{C}_{4} \mathrm{H}_{2} \mathrm{~N}_{2} \mathrm{O}_{2} \mathrm{Br}$ & 99.60 & 100 \\
\hline \multirow{7}{*}[\mathrm{Mn}(\mathrm{Br}-\mathrm{U})_{2}(\mathrm{H}_{2}\mathrm{O})_{2}]{$\cdot 4 \mathrm{H}_{2} \mathrm{O}(\mathbf{1})$} & $1^{\text {st }}$ step & 138 & $4 \mathrm{H}_{2} \mathrm{O}$ & 13.32 & 13.27 \\
\hline & $2^{\text {nd }}$ step & 280 & $2 \mathrm{H}_{2} \mathrm{O}$ & 6.71 & 6.63 \\
\hline & $3^{\text {rd }}$ step & 331 & --- & --- & --- \\
\hline & $4^{\text {th }}$ step & 510 & --- & --- & --- \\
\hline & $5^{\text {th }}$ step & 707 & $\mathrm{C}_{8} \mathrm{H}_{4} \mathrm{Br}_{2} \mathrm{~N}_{4} \mathrm{O}_{3}$ & 68.07 & 67.03 \\
\hline & Total loss & ---- & $\mathrm{C}_{8} \mathrm{H}_{16} \mathrm{Br}_{2} \mathrm{~N}_{4} \mathrm{O}_{9}$ & 88.10 & 86.93 \\
\hline & Residue & ---- & $\mathrm{MnO}$ & 11.90 & 13.04 \\
\hline \multirow{7}{*}[\mathrm{Cd}(\mathrm{Br}-\mathrm{U})_{2}]{$\cdot 2 \mathrm{H}_{2} \mathrm{O}(\mathbf{2})$} & $1^{\text {st }}$ step & 210 & $2 \mathrm{H}_{2} \mathrm{O}$ & 6.30 & 6.82 \\
\hline & $2^{\text {nd }}$ step & 407 & ---- & ---- & ----- \\
\hline & $3^{\text {rd }}$ step & 539 & --- & ---- & --- \\
\hline & $4^{\text {th }}$ step & 724 & --- & ---- & --- \\
\hline & $5^{\text {th }}$ step & 925 & $\mathrm{C}_{8} \mathrm{H}_{4} \mathrm{Br}_{2} \mathrm{~N}_{4} \mathrm{O}_{3}$ & 71.20 & 68.88 \\
\hline & Total loss & ---- & $\mathrm{C}_{8} \mathrm{H}_{8} \mathrm{Br}_{2} \mathrm{~N}_{4} \mathrm{O}_{5}$ & 77.50 & 75.70 \\
\hline & Residue & ---- & $\mathrm{CdO}$ & 22.50 & 24.30 \\
\hline \multirow{7}{*}[\mathrm{Cu}(\mathrm{Br}-\mathrm{U})_{2}(\mathrm{H}_{2}\mathrm{O})_{2}]{$\cdot 2 \mathrm{H}_{2} \mathrm{O}(\mathbf{3})$} & $1^{\text {st }}$ step & 120 & $2 \mathrm{H}_{2} \mathrm{O}$ & 6.50 & 6.99 \\
\hline & $2^{\text {nd }}$ step & 240 & $2 \mathrm{H}_{2} \mathrm{O}$ & 7.00 & 6.99 \\
\hline & $3^{\text {rd }}$ step & 283 & --- & --- & --- \\
\hline & $4^{\text {th }}$ step & 355 & --- & --- & --- \\
\hline & $5^{\text {th }}$ step & 627 & $\mathrm{C}_{8} \mathrm{H}_{4} \mathrm{Br}_{2} \mathrm{~N}_{4} \mathrm{O}_{4}$ & 75.00 & 70.59 \\
\hline & Total loss & ---- & $\mathrm{C}_{8} \mathrm{H}_{12} \mathrm{Br}_{2} \mathrm{~N}_{4} \mathrm{O}_{7}$ & 87.50 & 84.57 \\
\hline & Residue & ---- & $\mathrm{CuO}$ & 12.50 & 15.43 \\
\hline \multirow{6}{*}[\mathrm{Co}(\mathrm{Br}-\mathrm{U})_{2}(\mathrm{H}_{2}\mathrm{O})_{2}]{$\cdot 4 \mathrm{H}_{2} \mathrm{O}(\mathbf{4})$} & $1^{\text {st }}$ step & 167 & $4 \mathrm{H}_{2} \mathrm{O}$ & 13.50 & 13.17 \\
\hline & $2^{\text {nd }}$ step & 269 & $2 \mathrm{H}_{2} \mathrm{O}$ & 7.50 & 6.59 \\
\hline & $3^{\text {rd }}$ step & 334 & --- & -- & ---- \\
\hline & $4^{\text {th }}$ step & 624 & $\mathrm{C}_{8} \mathrm{H}_{4} \mathrm{Br}_{2} \mathrm{~N}_{4} \mathrm{O}_{3}$ & 65.75 & 66.54 \\
\hline & Total loss & ---- & $\mathrm{C}_{8} \mathrm{H}_{16} \mathrm{Br}_{2} \mathrm{~N}_{4} \mathrm{O}_{9}$ & 86.75 & 86.30 \\
\hline & Residue & ---- & $\mathrm{CoO}$ & 13.25 & 13.70 \\
\hline \multirow{8}{*}[\mathrm{Ni}(\mathrm{Br}-\mathrm{U})_{2}(\mathrm{H}_{2}\mathrm{O})_{2}]{$\cdot 4 \mathrm{H}_{2} \mathrm{O}(\mathbf{5})$} & $1^{\text {st }}$ step & 170 & $4 \mathrm{H}_{2} \mathrm{O}$ & 13.50 & 13.18 \\
\hline & $2^{\text {nd }}$ step & 275 & $2 \mathrm{H}_{2} \mathrm{O}$ & 6.90 & 6.59 \\
\hline & $3^{\text {rd }}$ step & 290 & ---- & ---- & --- \\
\hline & $4^{\text {th }}$ step & 393 & ---- & ---- & 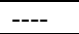 \\
\hline & $5^{\text {th }}$ step & 564 & ---- & ---- & --- \\
\hline & $6^{\text {th }}$ step & 762 & $\mathrm{C}_{8} \mathrm{H}_{4} \mathrm{Br}_{2} \mathrm{~N}_{4} \mathrm{O}_{3}$ & 67.10 & 66.57 \\
\hline & Total loss & ------ & $\mathrm{C}_{8} \mathrm{H}_{16} \mathrm{Br}_{2} \mathrm{~N}_{4} \mathrm{O}_{9}$ & 87.50 & 86.34 \\
\hline & Residue & ------ & $\mathrm{NiO}$ & 12.50 & 13.66 \\
\hline \multirow{7}{*}[\mathrm{Ag}(\mathrm{Br}-\mathrm{U})(\mathrm{Br}-\mathrm{U}-\mathrm{H})]{$\cdot 2 \mathrm{H}_{2} \mathrm{O}(\mathbf{6})$} & $1^{\text {st }}$ step & 160 & $2 \mathrm{H}_{2} \mathrm{O}$ & 6.37 & 6.86 \\
\hline & $2^{\text {nd }}$ step & 299 & ---- & ---- & ---- \\
\hline & $3^{\text {rd }}$ step & 393 & ---- & ---- & ---- \\
\hline & $4^{\text {th }}$ step & 625 & ---- & ---- & ---- \\
\hline & $5^{\text {th }}$ step & 819 & $\mathrm{C}_{8} \mathrm{H}_{5} \mathrm{Br}_{2} \mathrm{~N}_{4} \mathrm{O}_{4}$ & 78.49 & 72.59 \\
\hline & Total loss & ---- & $\mathrm{C}_{8} \mathrm{H}_{9} \mathrm{Br}_{2} \mathrm{~N}_{4} \mathrm{O}_{6}$ & 82.49 & 79.45 \\
\hline & Residue & ---- & $\mathrm{Ag}$ & 18.94 & 20.55 \\
\hline
\end{tabular}

range of $77.50-88.10 \%$, which in good agreement with the theoretical values for the suggested structures (75.70-86.94\%). The decomposition processes for the $\mathrm{Mn}(\mathrm{II}), \mathrm{Cd}(\mathrm{II}), \mathrm{Cu}(\mathrm{II}), \mathrm{Co}(\mathrm{II})$ and $\mathrm{Ni}$ (II) complexes left residue of the corresponding metal(II) oxides. The TGA thermograms show that the ratios of these metal oxide residues are in the range of $11.90-22.50 \%$ of the total weight, where the theoretical ratio calculated for the metal oxides resulting from the suggested 
structures is between $13.04-24.30 \%$. The decomposition process for the $\operatorname{Ag}(\mathrm{I})$ complex left residue of silver metal $(\mathrm{Ag})$, corresponding to $18.94 \%$ of the total weight of complex, in good agreement with the calculated ratio of silver metal in the suggested $\mathrm{Ag}(\mathrm{I})$ complex $(20.55 \%)$ [39].
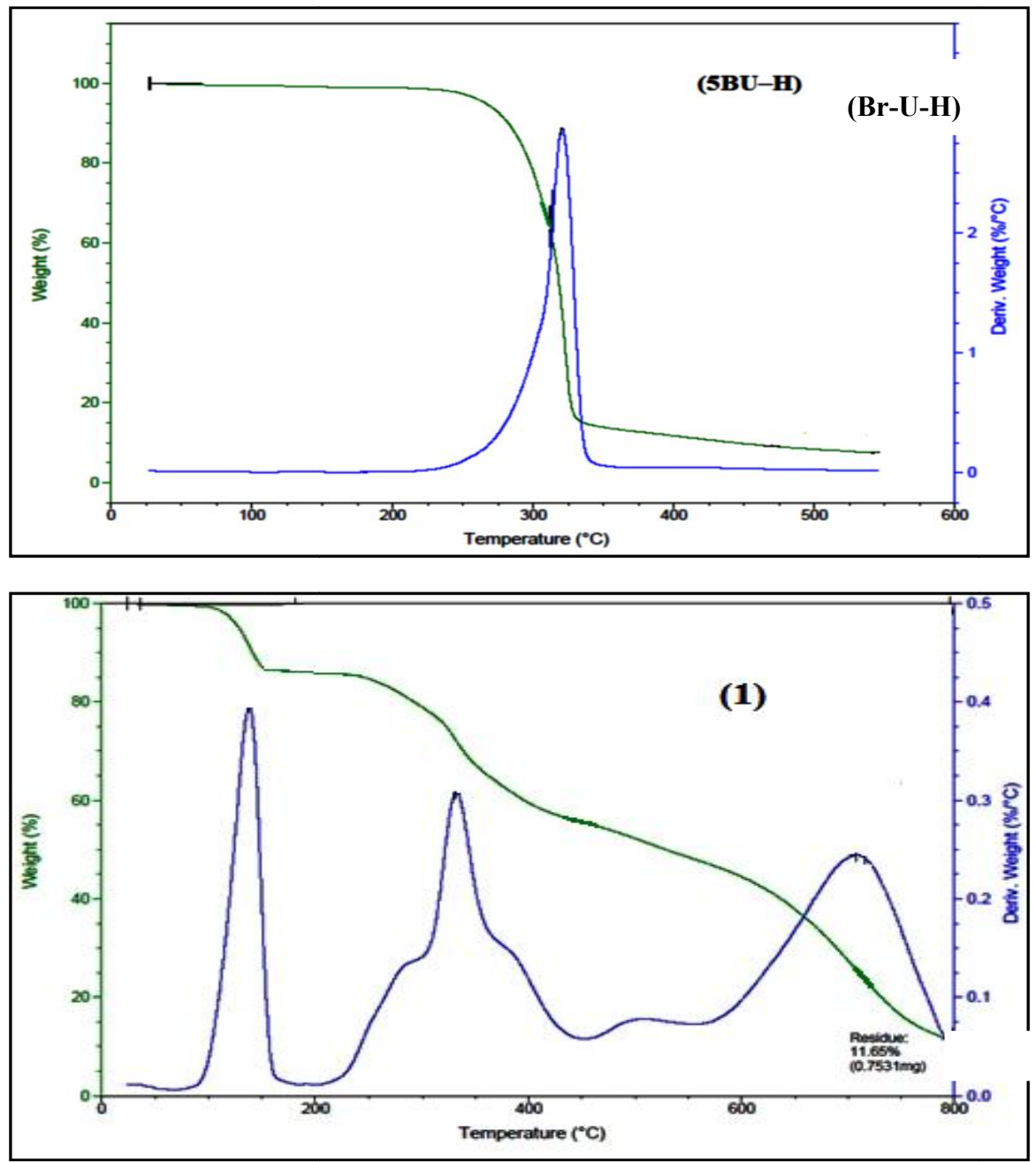

Bull. Chem. Soc. Ethiop. 2019, 33(2) 

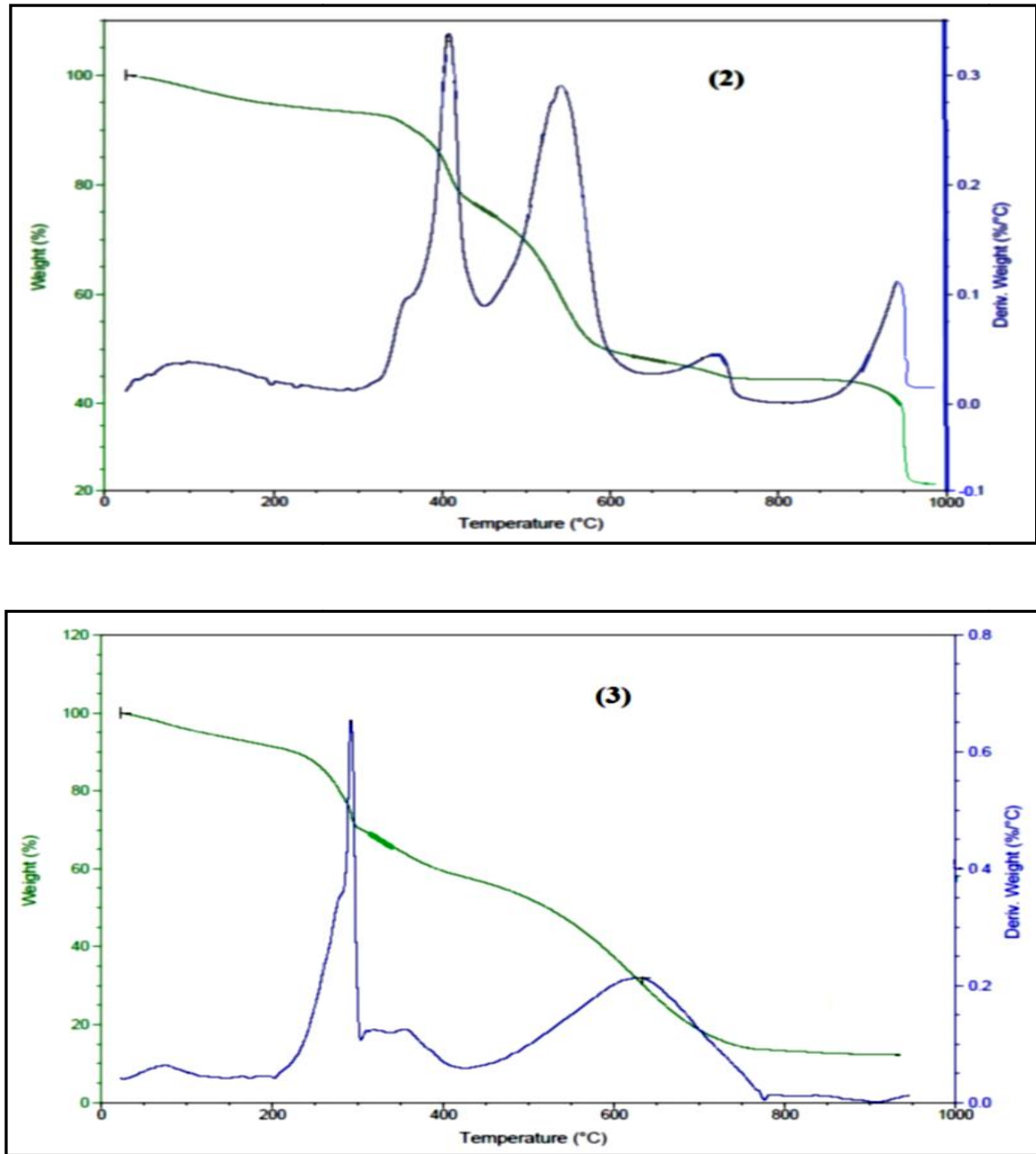

Bull. Chem. Soc. Ethiop. 2019, 33(2) 

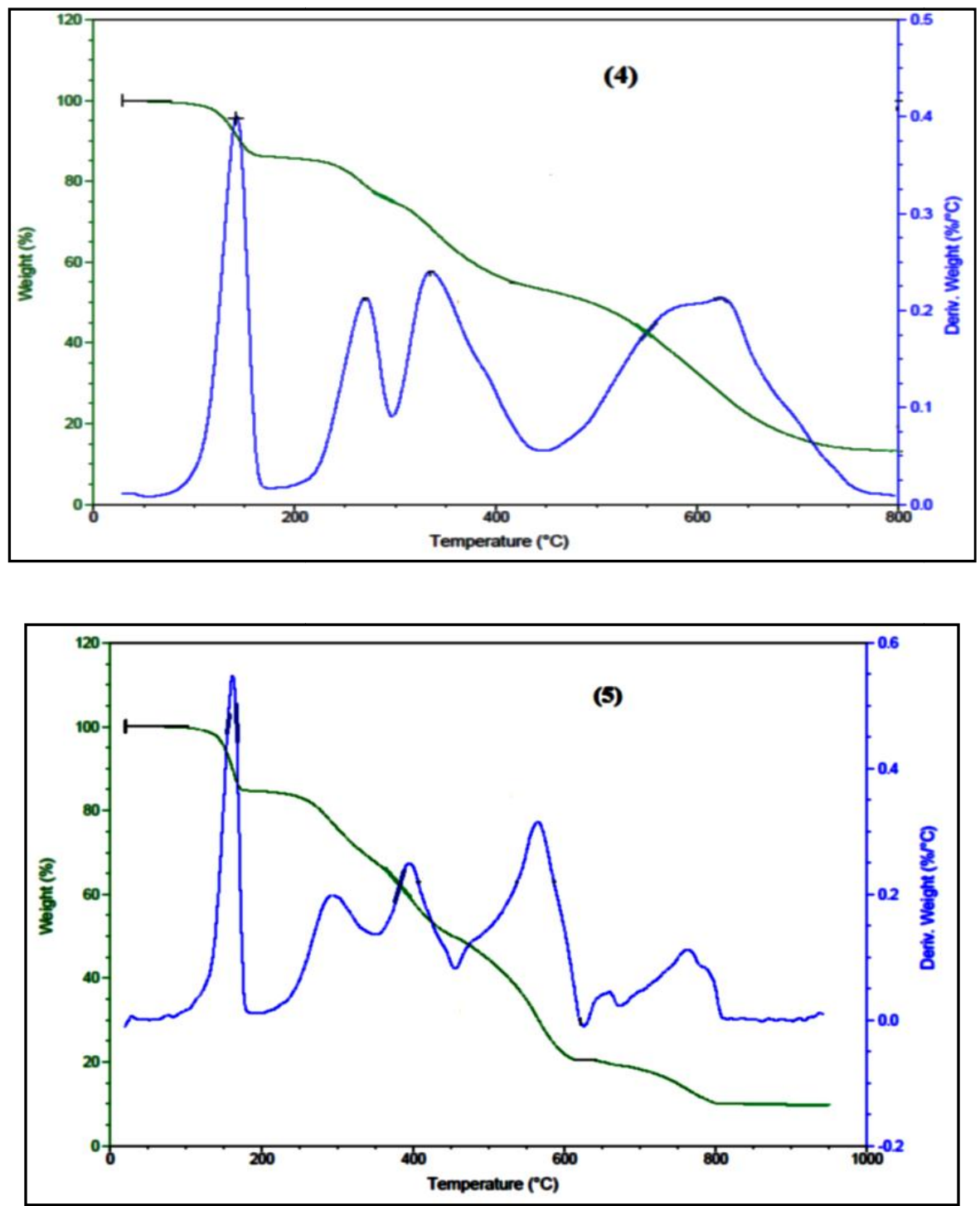

Bull. Chem. Soc. Ethiop. 2019, 33(2) 


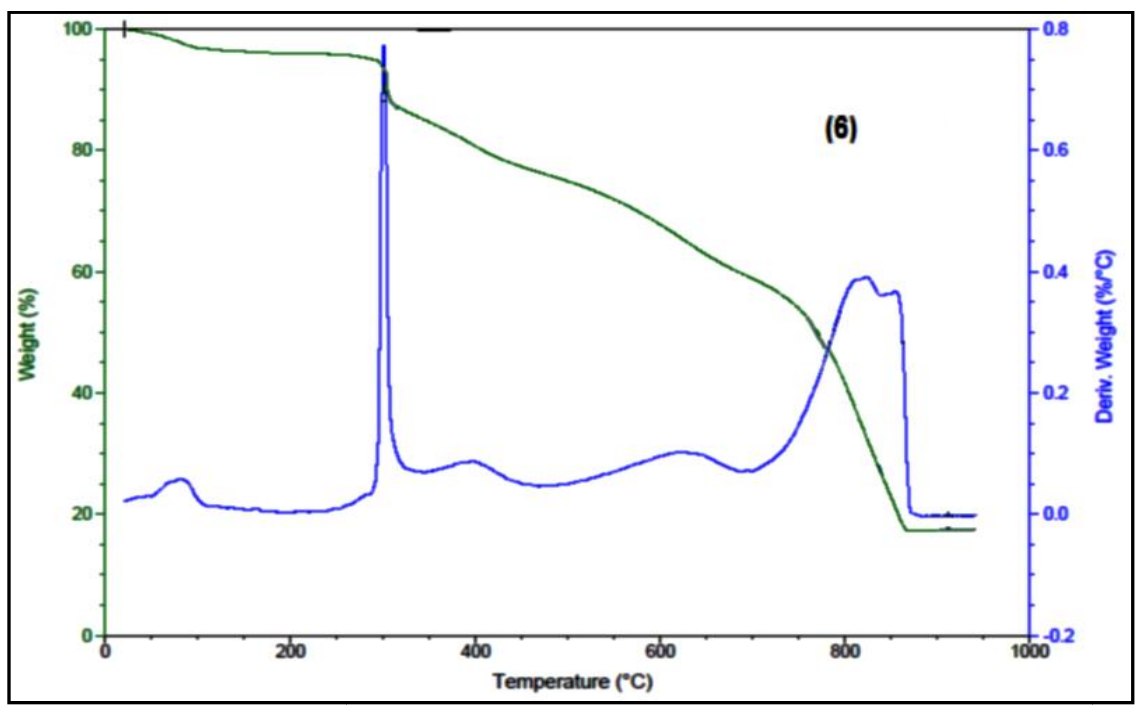

Figure 1. Thermogravimetric Analyses (TGA, DTG) of free ligand $(\mathrm{Br}-\mathrm{U}-\mathrm{H})$ and its complexes (1-6).

\section{Antimicrobial activity}

The in vitro antibacterial activities of the compounds under investigation were tested against four bacterial strains, i.e. two Gram-positive bacteria (B. subtillis and S. aureus), and two Gramnegative bacteria (E. coli and $P$. aeruginosa), by an agar well diffusion method (Table 4).

Complexes 1, 3 and $\mathbf{4}$ showed good activities against the Gram-positive bacterial strains $B$. subtillis and $S$. aureus and moderate activity against Gram-negative bacterial strains $E$. coli and $P$. aeruginosa. Complex $\mathbf{5}$ showed good activities against the selected bacterial strains. Complexes $\mathbf{2}$ and $\mathbf{6}$ showed excellent activities compared to the positive control against Grampositive $B$. subtillis and $S$. aureus and moderate activity against Gram-negative $E$. coli and $P$. aeruginosa. The remarkable activities of the complexes may be due to structural changes in the geometries of the molecules and the type of metal ion [40].

Table 4. Antibacterial activities for the 5-bromouracil complexes (1-6).

\begin{tabular}{|l|c|c|c|c|}
\hline \multicolumn{4}{|c|}{ Inhibition zone diameter in mm } \\
\hline \multirow{2}{*}{ Compounds } & \multicolumn{2}{|c|}{ Gram-positive } & \multicolumn{2}{c|}{ Gram-negative } \\
\cline { 2 - 5 } & $\begin{array}{c}\text { Bacillus } \\
\text { subtillis }\end{array}$ & $\begin{array}{c}\text { Staphylococcus } \\
\text { aureus }\end{array}$ & Escherichia coli & $\begin{array}{c}\text { Pseudomonas } \\
\text { aeruginosa }\end{array}$ \\
\hline$\left[\mathrm{Mn}(\mathrm{Br}-\mathrm{U})_{2}\left(\mathrm{H}_{2} \mathrm{O}\right)_{2}\right] \cdot 4 \mathrm{H}_{2} \mathrm{O}(\mathbf{1})$ & 17 & 17 & 12 & 12 \\
\hline$\left[\mathrm{Cd}(\mathrm{Br}-\mathrm{U})_{2}\right] \cdot 2 \mathrm{H}_{2} \mathrm{O}(\mathbf{2})$ & 18 & 18 & 13 & 13 \\
\hline$\left[\mathrm{Cu}\left(\mathrm{Br}-\mathrm{U}_{2}\left(\mathrm{H}_{2} \mathrm{O}\right)_{2}\right] \cdot 2 \mathrm{H}_{2} \mathrm{O}(\mathbf{3})\right.$ & 15 & 15 & 12 & 12 \\
\hline$\left[\mathrm{Co}\left(\mathrm{Br}-\mathrm{U}_{2}\left(\mathrm{H}_{2} \mathrm{O}\right)_{2}\right] \cdot 4 \mathrm{H}_{2} \mathrm{O}(\mathbf{4})\right.$ & 14 & 14 & 13 & 13 \\
\hline$\left[\mathrm{Ni}(\mathrm{Br}-\mathrm{U})_{2}\left(\mathrm{H}_{2} \mathrm{O}\right)_{2}\right] \cdot 4 \mathrm{H}_{2} \mathrm{O}(\mathbf{5})$ & 15 & 16 & 14 & 14 \\
\hline$[\mathrm{Ag}(\mathrm{Br}-\mathrm{U})(\mathrm{Br}-\mathrm{U}-\mathrm{H})] \cdot 2\left(\mathrm{H}_{2} \mathrm{O}\right)(\mathbf{6})$ & 20 & 18 & 13 & 14 \\
\hline DMSO & 0.0 & 0.0 & 0.0 & 0.0 \\
\hline Ampicillin & 21 & 19 & 23 & 17 \\
\hline
\end{tabular}

Standard error \pm 1 . 


\section{CONCLUSION}

In our study, we have prepared different types of 5-bromouracil-metal ion complexes by the reaction of 5-bromoouracil with $\mathrm{MnCl}_{2} \cdot 4 \mathrm{H}_{2} \mathrm{O}, \mathrm{CdCl}_{2} \cdot 2.5 \mathrm{H}_{2} \mathrm{O}, \mathrm{CuSO}_{4} \cdot 5 \mathrm{H}_{2} \mathrm{O}$, $\left(\mathrm{CH}_{3} \mathrm{COO}\right)_{2} \mathrm{Co} \cdot 4 \mathrm{H}_{2} \mathrm{O},\left(\mathrm{CH}_{3} \mathrm{COO}\right)_{2} \mathrm{Ni} \cdot 4 \mathrm{H}_{2} \mathrm{O}$ and $\mathrm{AgNO}_{3}$, respectively. The complexes were structurally characterized by melting point, elemental analyses measurements, electrical conductivity, IR and ${ }^{1} \mathrm{H}$ NMR spectroscopy. The obtained data indicated that the ligand interacted with the metal ions in its mononegatively charged enol form in a bidentate fashion and the complexes have a 1:2 metal-to-ligand stoichiometry. Thermogravimetric analyses (TGA and DTG) were also achieved. The data obtained agreed with the proposed structures and showed that the complexes were finally decomposed to the corresponding metal oxide or metal. The prepared 5-bromouracil- $\mathrm{M}^{2+}$ complexes were screened for their antimicrobial activities by an agar-well diffusion technique using DMSO as a solvent and showed that the complexes were potent antimicrobial.

\section{REFERENCES}

1. Garrettand, R.H.; Grisham, D.M. Principles of Biochemistry with a Human Focus, Brooks/Cole Thomson Learning: USA; 1997.

2. Oladipo, M.A.; Isola, K.T. Coordination possibility of uracil and applications of some of its complexes. RJPBCS 2013, 4, 386-394.

3. Wright, E.G.; Gambinu, J.J. Quantitative structure-activity relationships of 6-anilinouracils as inhibitors of Bacillus subtilis DNA polymerase III. J. Med. Chem. 1984, 27, 181-185.

4. Watnabe, A.K.; Harada, K.; Zeidler, J.; Adamic, J.M.; Takahashi, K.; Ren, W.Y.; Cheng, L. C.; Fox, J.J.; Chou, T.C. Synthesis and anti-HIV-1 activity of 2'-"up"-fluoro analogs of active anti-AIDS nucleosides 3'-azido-3'-deoxythymidine (AZT) and 2',3'-dideoxycytidine (DDC). J. Med. Chem. 1990, 33, 2145-2150.

5. Xiong, J.; Lan, Y.J.; Zhang, S.F. Lanthanum(III) complex of uracil-1-acetic acid, a new 2D coordination polymer $\left[\mathrm{La}(\mathrm{Phen})(\mathrm{UA})_{3}\right]_{\mathrm{n}} \cdot \mathrm{nH}_{2} \mathrm{O}$ (Phen $=1,10$-phenanthroline and UA $=$ uracil-1-acetate). Russian J. Coord. Chem. 2007, 33, 306-311.

6. Refat, M.S.; El-Korash, S.A.; Ahmed, A.S. A convenient method for the preparation of barbituric and thiobarbituric acid transition metal complexes. Spectrochim. Acta A Mol. Biomol. Spectrosc. 2008, 71, 1084-1094.

7. Casas, J.S.; Castellans, E.E.; Louce, M.D.; Ellena, J.; Sanchez, A.; Sordo, J.; Taboada, C. A gold(I) complex with a vitamin $\mathrm{K}_{3}$ derivative: Characterization and antitumoral activity. $J$. Inorg. Biochem. 2006, 100, 1858-1860.

8. Katsung, B.G. Basic and Clinical Pharmacology, 4th ed., Appleton and Lange: Lebanon; 1989.

9. Schroeder, S.A.; Krupp, M.A.; Tierney, L.M.Jr.; McPhee, S.J. Current Medical Diagnosis and Treatment, Appleton and Lange: Prentice-Hall, London; 1990.

10. Akyuz, S.; Akyuz, T.; Akalin, E. Investigation of adsorption of 5-fluorouracil and 5bromouracil onto sepiolite and loughlinite: An IR spectroscopic study. Asian J. Chem. 2014, $26,4875-4878$.

11. Fliegerová, O.; Škodová, H.; Farkaš, J.; Škoda, J. The molecular mechanism of antibacterial activity of 5-substituted halogen derivatives of 2,3-dihydro-1,3-6h-oxazine-2,6-dione-3oxauracil. Collect. Czech. Chem. Commun. 1976, 41, 2073-2078.

12. Orozco, M.; Hernandez, B.; Luque, J. Tautomerism of 1-methyl derivatives of uracil, thymine and 5-bromouracil. Is Tautomerism the basis for the mutagenicity of 5bromouridine?. J. Phys. Chem. B. 1998, 102, 5228-5233. 
13. Paula, A.; Camargo, M. An electrochemical study of the adsorption and coadsorption behavior of selected purines, pyrimidines and nucleosides on $A u(I I I)$. PhD thesis, Freie Universität Berlin, Germany, 2004, pp 75-102.

14. Zammenhof, S.; De Giovanni, S.; Greer, S. Induced gene unstabilization. Nature 1958, 181, 827-829.

15. Lawrence, T.S.; Davis, M.A.; Maybaum, J.; Stetson, P.L.; Ensminger, W.D. Fluorodeoxyuridine-mediated modulation of lododeoxyuridine incorporation and radiosensitization in human colon cancer cells in vitro and in vivo. Cancer Res. 1991, 51, 3900-3905.

16. Watson, J.D.; Crick, F.H.C. Molecular structure of nucleic Acids: A structure for deoxyribose nucleic acid. Nature 1953, 171, 737-738.

17. Rastogi, V.K.; Lal, B.; Sharma, Y.C.; Jain, C.L. Metal Ions in Biology and Medicine, John Libbey Eurotent: France; 1992, p 184.

18. Rastogi, V.K.; Singh, A.; Chawla, S.C.; Gupta, S.L. $5^{\text {th }}$ International Conference on the Spectroscopy of Biological Molecules, Department of Chemical Engineering, National Technical University, Athens, Greece, Kluwer Academic Publishers \& Springer Science + Business Media: Dordrecht; 1993.

19. Singh, U.P.; Ghose, R.; Ghose, A.K. Characterization of metal chelation with a mutagenic agent, 5-bromouracil. Bull. Chem. Soc. Japan. 1990, 63, 1226-1229.

20. Wysor, M.S.; Zollinhofer, R.E. Antibacterial properties of silver chelates of uracil and uracil derivatives in vitro. Chemotherapy 1972, 17, 188-199.

21.Greenwood, D.; Snack, R.; Peurtherer, J. Medical Microbiology: A Guide to Microbial Infections: Pathogenesis, Immunity, Laboratory Diagnosis and Control, Churchill Livingstone: Edinburgh, United Kingdom; 1997, p 15.

22. Greenwood, D. Antimicrobial Chemotherapy, (Part II) Laboratory Aspects of Antimicrobial Therapy, Bailliere Tindall: London; 1983, pp 71-101.

23. Marmur, J. A procedure for the isolation of deoxyribonucleic acid from micro-organisms. $J$. Mol. Biol. 1961, 3, 208-218.

24. Reddy, V.; Patil, N.; Angadi, S.D. Synthesis, characterization and antimicrobial activity of $\mathrm{Cu}(\mathrm{II}), \mathrm{Co}(\mathrm{II})$ and $\mathrm{Ni}(\mathrm{II})$ complexes with $\mathrm{O}, \mathrm{N}$, and $\mathrm{S}$ donor ligands. E. J. Chem. 2008, 5, 577. DOI: $10.1155 / 2008 / 170631$.

25. Betina, V. The Chemistry and Biology of Antibiotics, Nauta, W.; Rekker, R. (Eds.), Elsevier: New York; 1983.

26. Boggess, R.K.; Zatko, D.A. The use of conductivity data for the structure determination of metal complexes. J. Chem. Educ. 1975, 52, 649.

27. Ten, G.N.; Burova, T.G.; Baranov, V.I. Calculation and interpretation of IR and resonant raman spectra of 5-halosubstituted uracils. J. Appl. Spectrosc. 2006, 73, 437-442.

28. Bertrand, B.; Nisole, C. Drancourt, J.M.; Dubuffet, T.; Bouchet, J.P.; Volland, J.P. Determination of cis and trans configurations in pentahydrobenzopyranopyrroles by FT-IR spectroscopy. Spectrochim. Acta Part A. 1996, 52, 1921-1923.

29. Suffren, Y.; Rollet, F.: Reber, C. Raman spectroscopy of transition metal complexes: molecular vibrational frequencies, phase transitions, isomers and electronic structure. Comments Inorg. Chem. 2011, 32, 246-276.

30. Nakamoto, K. Infrared and Raman Spectra of Inorganic and Coordination Compounds. 6th ed., John Wiley and Sons Inc.: Canada; 2009.

31.Günzler, H.; Germlich, H. IR Spectroscopy: An Introduction. Wiely-VCH Verlag GmbH 69469: Weinheim (F.R.G.); 2002.

32. Mostafa, S.I.; Kabil, M.A.; Saad, E.M.; El-Asmy, A.A. Ligational and analytical applications of a uracil derivative toward some transition metal ions. J. Coord. Chem. 2006, 59, 279-293. 
33. Sarkar, A.R.; Ghosh, P. Interaction of divalent metal ions with uracil. I. Oxygen coordinating uracil complexes of $\mathrm{Mn}(\mathrm{II}), \mathrm{Fe}(\mathrm{II}), \mathrm{Co}(\mathrm{II}), \mathrm{Ni}(\mathrm{II})$ and $\mathrm{Cu}(\mathrm{II})$. Inorg. Chim. Acta 1983, 78, L39-L41.

34. Kufelnicki, A.; Jaszczak, J.; Kalinowska-Lis, U.; Wardak, C.; Ochocki, J. Complexes of uracil (2,4-dihydroxypyrimidine) derivatives. J. Solution Chem. 2006, 35, 739-751.

35. Gaballa, A.S.; Teleb, S.M.; Asker, M.S.; Yalçin, E.; Seferoğlu, Z. Synthesis, spectroscopic properties and antimicrobial activity of some new 5-phenylazo-6-aminouracil-vanadyl complexes. J. Coord. Chem. 2011, 64, 4225-4243.

36. Averill, B.A. Principles of General Chemistry; 2012; Silberberg; Martin, S. (Eds.), Chemistry: The Molecular Nature of Matter and Change, 4th ed., McGraw Hill Company; New York; 2006; Housecroft, C.E.; Sharpe, A.G. Inorganic Chemistry, 2nd ed., Pearson Education Limited: England; 2005.

37. Macomber, R.S. Complete Introduction to Modern NMR Spectroscopy, John Wiley and Sons: New York; 1998.

38. Günther, H. NMR Spectroscopy, Basic principles, Concepts and Applications in Chemistry, 2nd ed., Wiley and Sons: New York; 2001.

39. Šesták, J.; Šimon, P. (Eds.) Thermal Analysis of Micro, Nano-and Non-Crystalline Materials, Springer Science+Business Media: Dordrecht; 2013.

40. Chaudhary, A.; Singh, R.V. Synthetic, structural and biological studies on divalent tin complexes of sixteen to twenty-four membered tetraaza macrocycles. Phosphorus Sulfur Silicon Related Elem. 2003, 178, 603-613; Sarin, N.; Arslan, S.; Logolu, E.; Sakiyan, I.; Sakiyan, N. Antimicrobial activities of N-(2-hydroxy-1-naphthalidene)-amino acid(glycine, alanine, phenylalanine, histidine, tryptophane) Schiff bases and their manganese(III) complexes. Biometals 2004, 17, 115-120; Jayabalakrishnan, C.; Natarajan, K.; Ruthenium(II) carbonyl complexes with tridentate Schiff bases and their antibacterial activity. Transit. Met. Chem. 2002, 27, 75-79. 